\title{
Effects of Azadirachta Indica Leaf Extract, Capping Agents, on the Synthesis of Pure And Cu Doped ZnO-Nanoparticles: A Green Approach and Microbial Activity
}

https://doi.org/10.1515/chem-2019-0018

received May 22, 2018; accepted October 3, 2018.

\section{Introduction}

Zinc oxide NPs has been under investigations by many researchers for its medical and other applications [1, 2]. Nanoscale zinc oxide shows unique properties in comparison to its micro size. These excellent properties of $\mathrm{ZnO}$ NPs are due to a large number of surface zinc ions and higher surface energy, which allows increased interaction of NPs with bacteria [3]. ZnO NPs, based on its unique properties such as non- toxicity, selectivity and biocompatibility with skin, makes it a suitable additive for textiles, sunscreen emulsion, and surfaces that come in contact with human body. Therefore, it can be regarded as a promising nano-material [4]. For the synthesis of ZnO NPs, the optimization of the synthesis parameters (like temperature, precursor, time, concentration, $\mathrm{pH}$ of reactant, etc) leads to NPs of different size, shape, and properties. The addition of a capping molecule could also greatly influence the size confinement of nanostructures, which in turn affects the physical properties. A significant variation in size is noted with the addition of capping molecules [5-12]. The functionality and efficiency of $\mathrm{ZnO}$ NPs and nanostructures can be enhanced by increasing and modifying their surface by adding dopants like copper $[13,14]$. For the environmental concern, researchers are using nontoxic chemicals and green methods for the synthesis of NPs for medical and other applications [15]. Several reactions require high temperature and pressure for initiation, while some require inert atmosphere protection, usage of toxic solvents, template and stabilizer for the synthesis of bioactive metal oxide NPs $[16,17]$. Green approaches using microorganisms, including bacteria, fungi, yeast, and plant extracts have been used in the synthesis of NPs $[17,18]$. Synthesis of NPs using microorganisms involves complicated processes due to cell cultures, and multiple purification steps. In this regard using plant extract methods for the synthesis of NPs has increasingly become a topic of interest as

\footnotetext{
*Corresponding author: Enyew Amare Zereffa, Department of Applied Chemistry, School of Applied Natural Science, Adama Science and Technology University, Adama, Ethiopia, E-mail: enyewama@yahoo.com

Dawit Tamire Handago, Bedasa Abdisa Gonfa: Department of Applied Chemistry, School of Applied Natural Science, Adama Science and Technology University, Adama, Ethiopia
} 
Table 1: Leave extract ratios used for the synthesis of nanoparticles.

\begin{tabular}{llll}
\hline No & Precursors & Ratio of leaf extract & Abbreviation \\
\hline 1 & $\mathrm{Zn}\left(\mathrm{CH}_{3} \mathrm{COO}\right)_{2} \cdot 2 \mathrm{H}_{2} \mathrm{O}$ & Neem Leaf Extract (1:1) Ratio(25 mL:25mL) & $\mathrm{ZnO}(1: 9)$ \\
2 & $\mathrm{Zn}\left(\mathrm{CH}_{3} \mathrm{COO}\right)_{2} \cdot 2 \mathrm{H}_{2} \mathrm{O}$ & Neem Leaf Extract (3:2) Ratio(30 mL:20mL) & $\mathrm{ZnO}(3: 2)$ \\
3 & $\mathrm{Zn}\left(\mathrm{CH}_{3} \mathrm{COO}\right)_{2} \cdot 2 \mathrm{H}_{2} \mathrm{O}$ & Neem Leaf Extract $(7: 3)$ Ratio(35 mL:15mL) & $\mathrm{ZnO}(7: 3)$ \\
4 & $\mathrm{Zn}\left(\mathrm{CH}_{3} \mathrm{COO}\right)_{2} \cdot 2 \mathrm{H}_{2} \mathrm{O}$ & Neem Leaf Extract $(9: 1)$ Ratio $(45 \mathrm{~mL}: 5 \mathrm{~mL})$ & $\mathrm{ZnO}(9: 1)$ \\
\hline
\end{tabular}

conventional chemical methods are expensive and require the use of organic solvents as reducing and capping agents $[19,20]$. In this work, we report the synthesis of pure and copper doped ZnO NPs using different ratios of Neem leaf extract in order to obtain a new product with the better antimicrobial activities [21, 22].

\section{Experimental}

\subsection{Preparation and Characterization}

Leaves of Neem (Azadirachta Indica) were collected and washed several times with sterilized distilled water. The aqueous extract of the sample was prepared by boiling $25 \mathrm{~g}$ of fresh leaves in $250 \mathrm{ml}$ glass beaker along with $100 \mathrm{ml}$ of double distilled water, at $60^{\circ} \mathrm{C}$ for 20 minutes while stirring with a magnetic stirrer until the color of the aqueous solution changed to brown. The extract was cooled to room temperature and filtered using Whatman filter paper. The extract was stored in a refrigerator to be used for the subsequent experiments [23]. To synthesize zinc oxide in (50:50) ratio $25 \mathrm{~mL}$ of neem leaf extract was added to $25 \mathrm{~mL}$ of $1 \mathrm{M}$ Zinc Acetate Dihydrate. The mixture was stirred continuously using magnetic stirrer and the solution was kept at $\mathrm{pH} 7.0$ by dropwise addition of 0.5 $M$ sodium hydroxide at room temperature resulted in the formation of a precipitate. The precipitate was filtered and washed repeatedly with water followed by ethanol in order to remove impurities, dried in an oven at $60^{\circ} \mathrm{C}$ overnight, ground to fine powder, and calcined at $400^{\circ} \mathrm{C}$ for 1 hour in Muffle furnace under air atmosphere. For the preparation of $\mathrm{Cu}$ doped $\mathrm{ZnO}\left(\mathrm{Zn}_{1-\mathrm{x}} \mathrm{Cu}_{\mathrm{x}} \mathrm{O}\right)$ with: $\mathrm{x}=0.005,0.01$ and 0.015, which are denoted as, (Cu-ZnO-05, Cu-ZnO-1 and $\mathrm{Cu}-\mathrm{ZnO}-15), 80 \mathrm{~mL} \mathrm{Zn}\left(\mathrm{CH}_{3} \mathrm{COO}\right)_{2} \cdot 2 \mathrm{H}_{2} \mathrm{O}(0.5033 \mathrm{M}), 10 \mathrm{~mL}$ $\mathrm{Cu}\left(\mathrm{NO}_{3}\right)_{2} \cdot 3 \mathrm{H}_{2} \mathrm{O}(0.02077 \mathrm{M})$ and $10 \mathrm{~mL}$ of neem leaf extract were mixed into $250 \mathrm{~mL}$ beaker. The same procedures were used with different ratios of aqueous extract as indicated in Table 1 for the synthesis of more NPs.

\subsection{Characterizations}

Thermal analysis was carried out using DTA-TGA apparatus (DTG-60H, Shimadzu Co, Japan) to determine the calcination temperature of the synthesized materials. $8.475 \mathrm{mg}$ of as-synthesized $\mathrm{ZnO}$ NPs using zinc acetate precursor and $8.117 \mathrm{mg}$ of $\mathrm{Cu}$ doped $\mathrm{ZnO} \mathrm{NP}$ samples were placed in a platinum crucible on the pan of the microbalance and heated to $1000^{\circ} \mathrm{C}$, using $\mathrm{Al}_{2} \mathrm{O}_{3}$ as inert material. The phase identifications of the synthesized NPs were investigated using D8 Advance Diffractometer. XRD patterns were recorded from $2 \theta=10$ to $80^{\circ}$ using $\mathrm{CuK}_{\alpha}(\mathrm{l}$ $=1.54 \AA$ ) at $40 \mathrm{kV}$, and Debye Scherrer's equation was used to estimate the crystallite size. The microstructure and surface composition of the NPs analysis were investigated with the scanning electron microscope (SEM) and Energy Dispersive X-ray Spectroscopy (EDS). The optical properties were investigated using UV-Vis spectroscopy. FTIR study was conducted on compressed pellets prepared by mixing powders with potassium bromide. Antibacterial activity of the synthesized NPs were tested against gram-positive (Staphylococcus aureus and Bacillus subtilis) and gram-negative (Escherichia coli and Proteus mirabilis) bacteria by the disc diffusion method using 200 $\mu \mathrm{L}$ of each sample with $10 \mathrm{mg} / \mathrm{ml}$ concentration saturated with $6 \mathrm{~mm}$ diameter disc placed on plate and incubated at $37^{\circ} \mathrm{C}$ for 24 hours.

Ethical approval: The conducted research is not related to either human or animal use.

\section{Results and Discussion}

\subsection{Thermal Analysis}

Figure 1 depicts the TGA-DTA curves for the thermal transformation of $\mathrm{Zn}$-complex with leaf extract. TGA showed a weight loss in two steps at 110 and $400^{\circ} \mathrm{C}$, while DTA showed one endothermic peak and one exothermic peak at 110 and $400^{\circ} \mathrm{C}$ respectively. The endothermic 

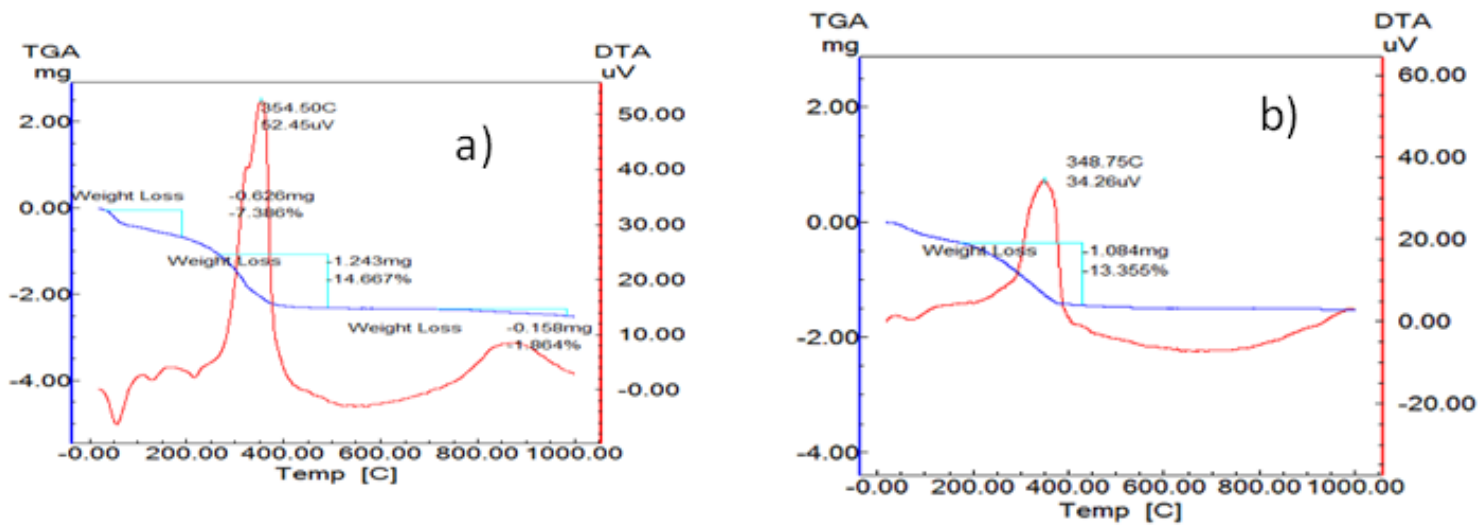

Figure 1: Thermal Analysis result of as synthesized oxides of a) $\mathrm{ZnO}$ and b) $\mathrm{Zn}_{0.995} \mathrm{Cu}_{0.005} \mathrm{O}$.

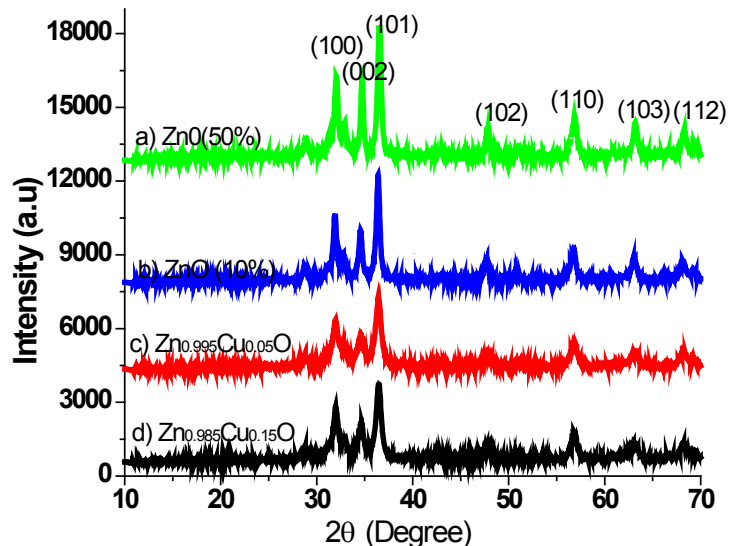

Figure 2: XRD patterns of pure $\mathrm{ZnO}$ synthesized using $(10 \%, 50 \%) \&$ Cu doped $\mathrm{Zn}_{1-\mathrm{x}} \mathrm{Cu}_{\mathrm{x}} \mathrm{O}(\mathrm{x}=0.5 \%$ \& $1.5 \%)$.

peak at $110^{\circ} \mathrm{C}$ was due to the removal of water and the peak at $400^{\circ} \mathrm{C}$ was due to decomposition of acetate ions and organic binders from leaf extracts. Dehydration from $\mathrm{Zn}$-complex at $110^{\circ} \mathrm{C}$ is endothermic. No considerable loss was observed after $400^{\circ} \mathrm{C}$ up to $1000^{\circ} \mathrm{C}$, which implies the $\mathrm{ZnO}$ and $\mathrm{Cu}$-doped $\mathrm{ZnO}$ NPs were thermally stable above $400^{\circ} \mathrm{C}$.

\subsection{XRD-Analysis}

Figure 2 ( $a, b, c \& d$ ) shows the XRD pattern of $\mathrm{ZnO}$ with $10 \%, 50 \%$ and $\mathrm{Zn}_{1-\mathrm{x}} \mathrm{Cu}_{\mathrm{x}} \mathrm{O}$ samples, where: $\mathrm{x}=0.005$ and 0.015 respectively. All the indexed diffraction peaks were matched with the hexagonal phase $\mathrm{ZnO}$ reported in JCPDS card No 36-1451 [24, 25]. The average crystallite size of ZnO (10\%), ZnO (50\%), $\mathrm{Cu}$ doped $\mathrm{ZnO}$ NPs for $\mathrm{Zn}_{0.995} \mathrm{Cu}_{0.005} \mathrm{O}$ and $\mathrm{Zn}_{0.985} \mathrm{Cu}_{0.015} \mathrm{O}$ were found to be $19.8 \mathrm{~nm}, 23.7 \mathrm{~nm}, 18.4$ $\mathrm{nm}$, and $16.1 \mathrm{~nm}$ respectively.

\subsection{HRSEM \& EDX-Ray Spectroscopy Analysis}

Figure 3(a-f), micrographs of pure and copper doped ZnONPs synthesized using different ratios of neem leaf extract revealed the influence of leaf extract or capping agent concentration on the grain size of synthesized materials.

As it is observed from SEM images of Figure 3 (b-f), the grain size of the particles increased when the volume ratios of leaf extract decreased from $50 \%$ to $10 \%$. This is due to the high concentration of the capping agents in the reaction media. The calcinations of the as-synthesized particles removed the bonded organic capping agents and counter anions through decomposition reactions. The surface morphology of the synthesized samples viewed through the high-resolution scanning electron microscope revealed the morphology of $\mathrm{ZnO}$ NPs synthesized from zinc acetate has agglomerated spherical shapes. On the SEM image of $\mathrm{Cu}$ doped $\mathrm{ZnO}\left(\mathrm{Zn}_{0.985} \mathrm{Cu}_{0.015} \mathrm{O}\right)$, Figure3c, cluster, flake-like and agglomerated spherical shapes were observed. The composition analysis of the samples determined by energy dispersive X-Ray spectroscopy (Figure 4) confirmed $\mathrm{Zn}$ and $\mathrm{O}$ are the major elements and the absence of foreign material in the spectrum.

\subsection{FT-IR spectroscopy Analysis}

Figure 5a-c shows the FT-IR spectra of synthesized pure \& copper doped ZnO NPs using zinc acetate before and after 

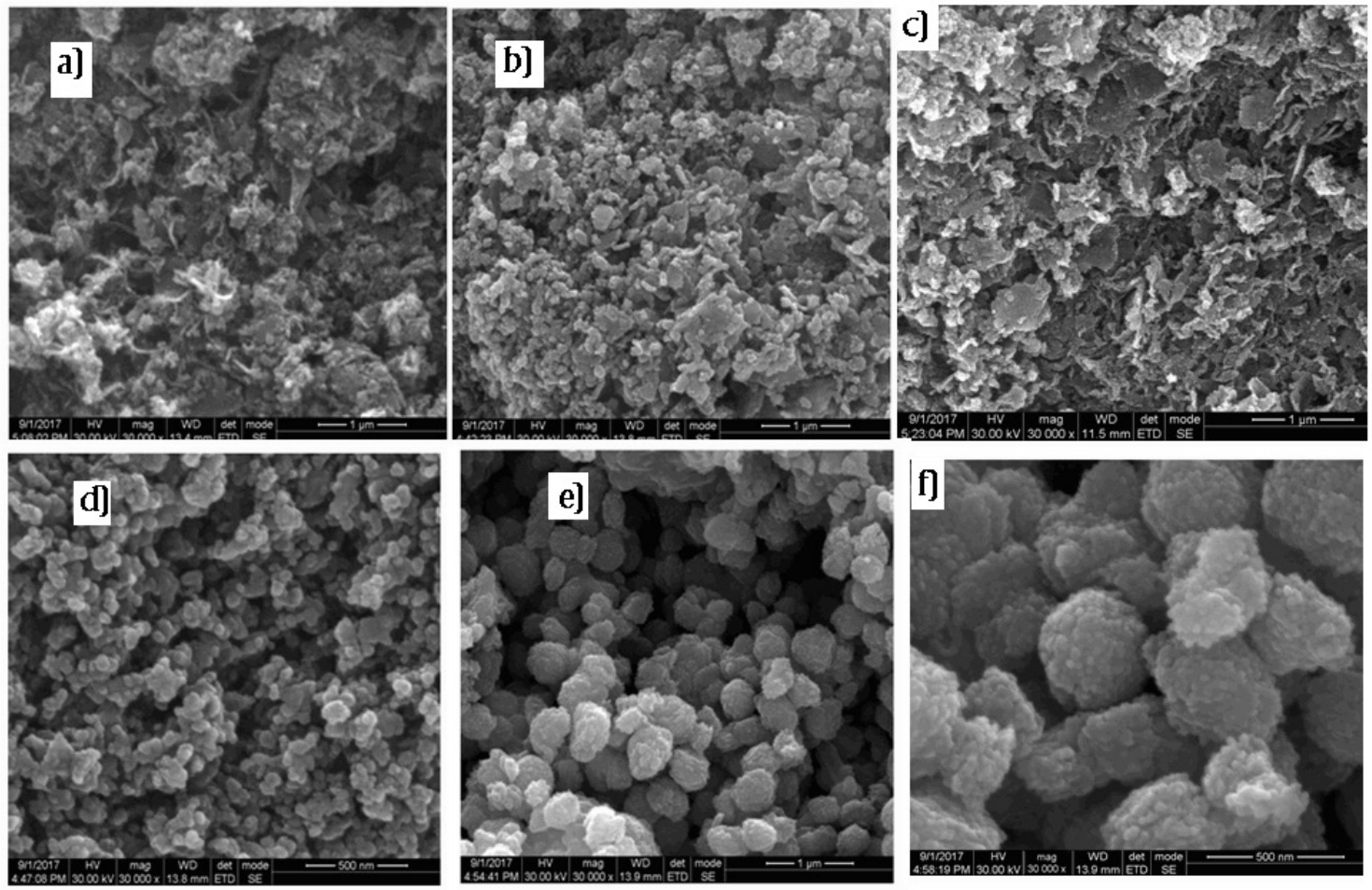

Figure 3(a-f): HRSEM micrographs of a) $\mathrm{ZnO}(1: 9)$ not calcined, b) $\mathrm{ZnO}(1: 9)$ calcined at $400^{\circ} \mathrm{C}$, c) Cu-doped $\mathrm{ZnO}(1: 9)$ calcined at $\left.400^{\circ} \mathrm{C}, \mathrm{d}\right)$ $\mathrm{ZnO}(3: 2)$ calcined at $400^{\circ} \mathrm{C}$, e) $\mathrm{ZnO}(3: 7)$ calcined at $400^{\circ} \mathrm{C}$, f) $\mathrm{ZnO}(1: 1)$ calcined at $400^{\circ} \mathrm{C}$

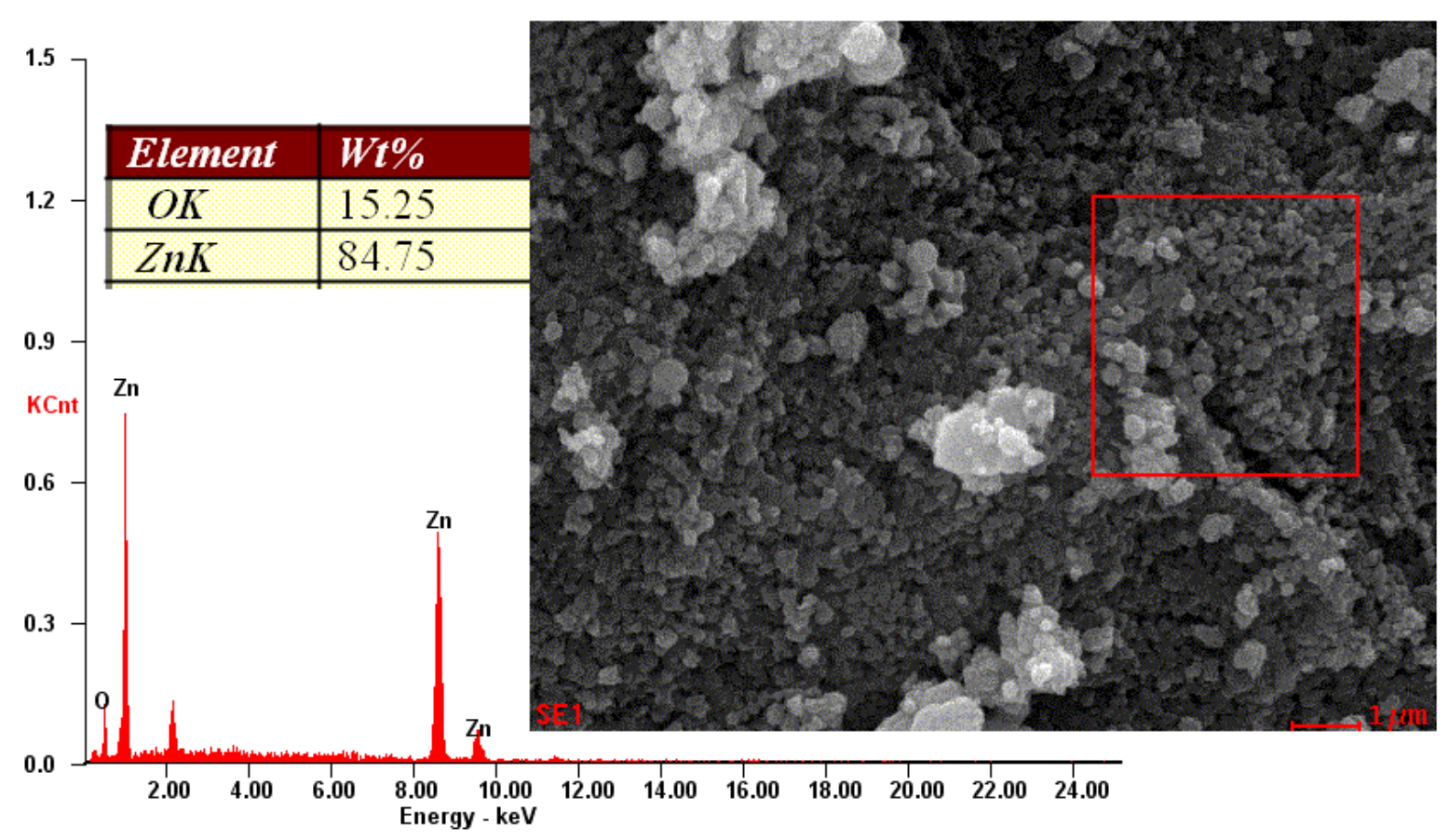

Figure 4: EDX spectrum of zinc oxide nanoparticles using zinc acetate. 

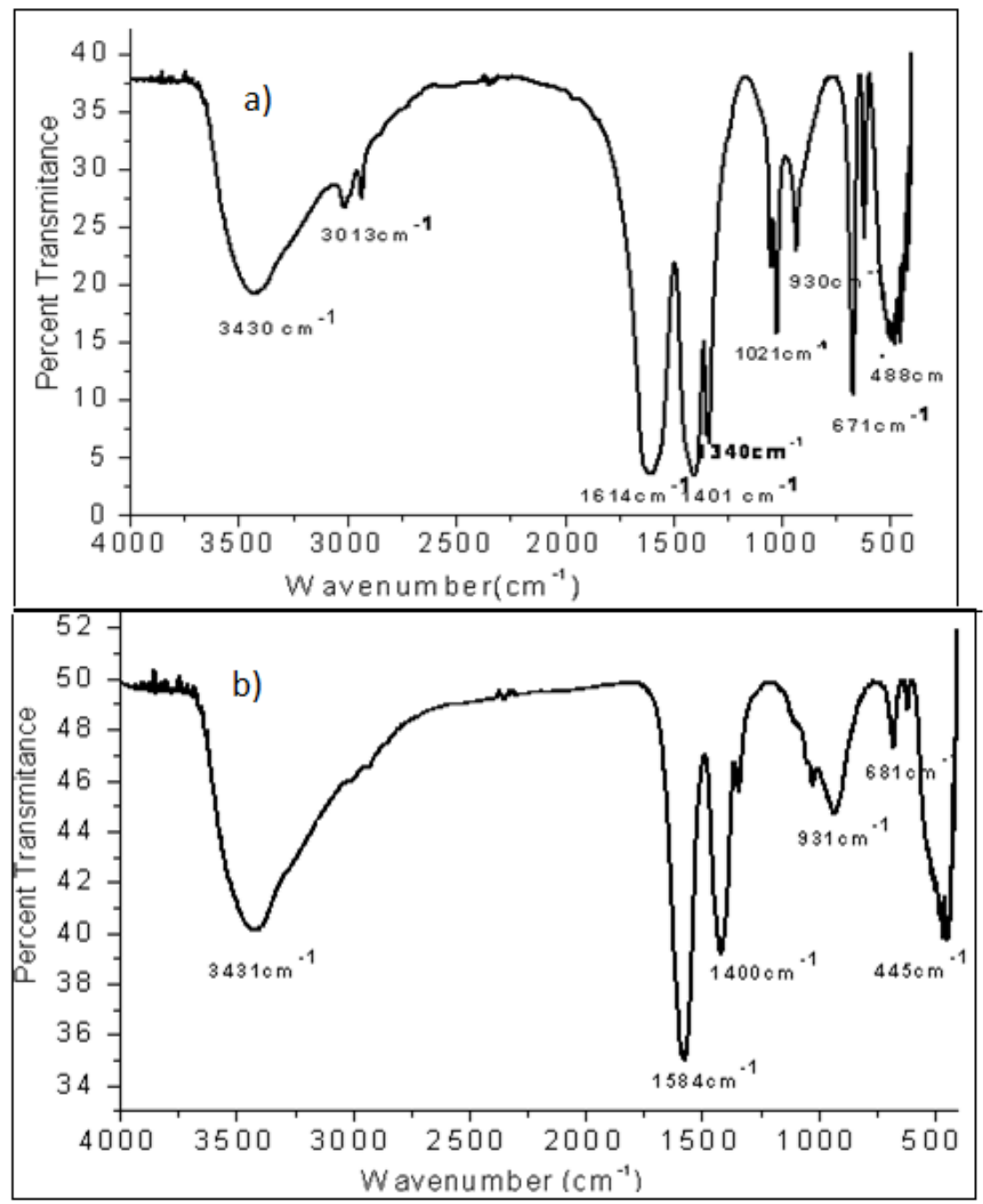

Figure 5a-b: FT-IR spectra of a) ZnO before calcinations \& b) Cu doped ZnO before calcinations.

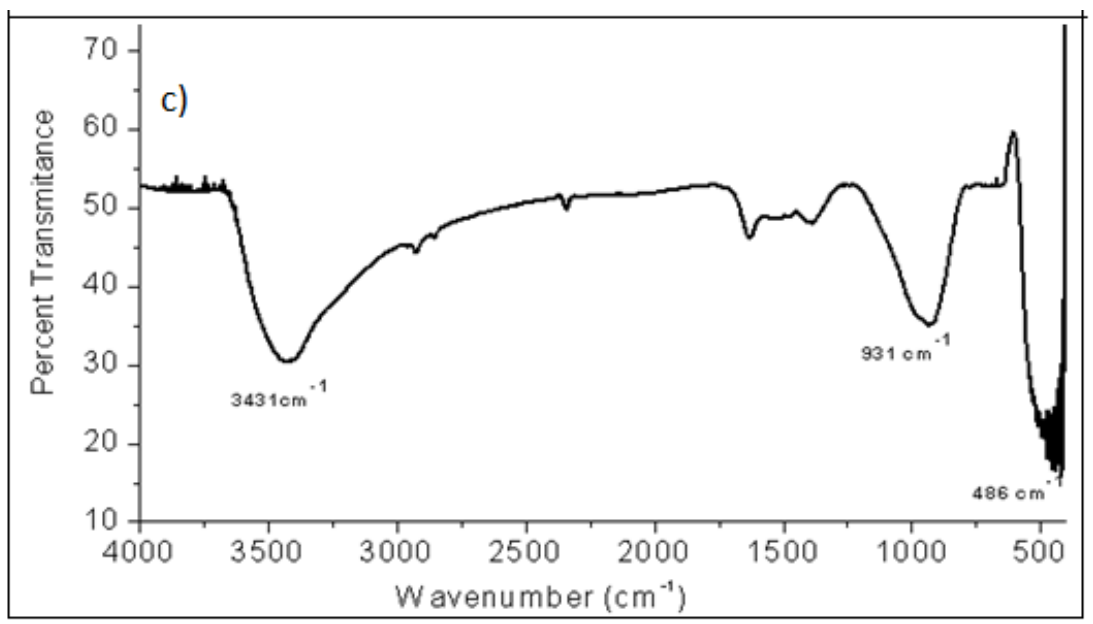

Figure 5.c: FT-IR spectra of $\mathrm{Cu}$ doped $\mathrm{ZnO}$ calcined at $400^{\circ} \mathrm{C}$ 
Table 2: $d$ - spacing $\left(d_{h k}\right)$ and Miller indices for $\mathrm{Zn}_{1-\mathrm{x}} \mathrm{Cu}_{\mathrm{x}} \mathrm{O}$ (where $\mathrm{x}=0.005$ and 0.015 ).

\begin{tabular}{|c|c|c|c|c|c|}
\hline \multicolumn{3}{|c|}{ For $\mathrm{Zn}_{0.995} \mathrm{Cu}_{0.005} \mathrm{O}$} & \multicolumn{3}{|c|}{ For $\mathrm{Zn}_{0.985} \mathrm{Cu}_{0.015} \mathrm{O}$} \\
\hline $2 \theta$ (degree) & $\begin{array}{l}\mathrm{d}-\text { spacing }\left(\mathrm{d}_{\mathrm{hk}}\right) \\
(\AA)\end{array}$ & $\begin{array}{l}\text { Miller Indices } \\
\mathrm{h} \mathrm{k} \mathrm{l}\end{array}$ & $2 \theta$ (degree) & $\begin{array}{l}\mathrm{d}-\text { spacing }\left(\mathrm{d}_{\mathrm{hk}}\right) \\
(\AA)\end{array}$ & $\begin{array}{l}\text { Miller Indices } \\
\text { h k l }\end{array}$ \\
\hline 31.99 & 2.7953 & 100 & 31.96 & 2.7979 & 100 \\
\hline 34.63 & 2.5880 & 002 & 34.60 & 2.5902 & 002 \\
\hline 36.46 & 2.4622 & 101 & 36.43 & 2.4642 & 101 \\
\hline 47.77 & 1.9023 & 102 & 47.74 & 1.9034 & 102 \\
\hline 50.94 & 1.7911 & 003 & 50.92 & 1.7918 & 003 \\
\hline 56.82 & 1.6189 & 110 & 56.80 & 1.6195 & 110 \\
\hline 63.12 & 1.4717 & 103 & 63.08 & 1.4725 & 103 \\
\hline 68.22 & 1.3735 & 112 & 68.20 & 1.3739 & 112 \\
\hline
\end{tabular}

Table 3: Different angles, their corresponding FWHM values and sizes of Cu doped ZnO NPs using zinc acetate and copper nitrate precursors.

\begin{tabular}{|c|c|c|c|c|c|}
\hline $2 \theta$ (degree) & $\begin{array}{l}\text { FWHM } \\
\text { (degree) }\end{array}$ & $\begin{array}{l}\text { Size of } \mathrm{Cu} \text { doped } \mathrm{ZnO} \text { NPs } \\
\left(\mathrm{Zn}_{0.995} \mathrm{Cu}_{0.005} \mathrm{O}\right)(\mathrm{nm})\end{array}$ & $2 \theta$ (degree) & $\begin{array}{l}\text { FWHM } \\
\text { (degree) }\end{array}$ & $\begin{array}{l}\text { Size of } \mathrm{Cu} \text { doped } \mathrm{ZnO} \\
\mathrm{NPs}\left(\mathrm{Zn}_{0.985} \mathrm{Cu}_{0.015} \mathrm{O}\right)(\mathrm{nm})\end{array}$ \\
\hline 31.99 & 0.4466 & 19.33 & 31.96 & 0.4417 & 19.53 \\
\hline 34.63 & 0.4482 & 19.40 & 34.60 & 0.4907 & 17.72 \\
\hline 36.46 & 0.4717 & 18.51 & 36.43 & 0.5512 & 15.84 \\
\hline 47.77 & 0.5756 & 15.83 & 47.74 & 0.6861 & 12.06 \\
\hline 50.94 & 0.4964 & 18.51 & 50.92 & 0.6507 & 14.05 \\
\hline 56.82 & 0.5130 & 18.39 & 56.80 & 0.5754 & 16.45 \\
\hline 63.12 & 0.6158 & 18.97 & 63.08 & 0.6313 & 15.45 \\
\hline 68.22 & 0.5583 & 17.96 & 68.20 & 0.5766 & 17.48 \\
\hline \multicolumn{2}{|c|}{ Average crystallite size } & 18.36 & \multicolumn{2}{|c|}{ Average crystallite size } & 16.07 \\
\hline
\end{tabular}

calcination. The intense absorption peaks in the region 430-520 $\mathrm{cm}^{-1}$ correspond to the standard peak of $\mathrm{ZnO}$ due to $\mathrm{ZnO}$ stretching frequency of $\mathrm{Zn}-\mathrm{O}$ bonds confirm the presence of $\mathrm{M}-\mathrm{O}$ vibration bands, and the wide absorption near $3430 \mathrm{~cm}^{-1}$ was due to $\mathrm{O}-\mathrm{H}$ stretching vibrations. The absorption occurred around $1614 \mathrm{~cm}^{-1}$ was due to aromatic $\mathrm{C}=\mathrm{C}$ ring stretching while the strong intensity at 1401 $\mathrm{cm}^{-1}$ was due to a- $\mathrm{CH}_{2}$ bending vibrations of aldehydes and ketones. The medium intensity around $1340 \mathrm{~cm}^{-1}$ was due to $\mathrm{O}-\mathrm{H}$ bending. Vibrations observed around 1021 and $930 \mathrm{~cm}^{-1}$ were because of $\mathrm{C}-\mathrm{O}$ and $\mathrm{C}-\mathrm{O}-\mathrm{H}$ stretching and bending respectively. Furthermore, Figure $4 \mathrm{c}$ indicates, the peaks intensity in $1400-1600 \mathrm{~cm}^{-1}$ range was relatively reduced, indicating the removal of the organic compound from the surface of $\mathrm{ZnO}$ NPs during calcinations. In the doped samples with copper, an absorption band near 681 $\mathrm{cm}^{-1}$ is also recognizable, which is related to vibration of $\mathrm{Cu}-\mathrm{O}$ bond $[26,27]$.

\subsection{UV - Visible Spectroscopy Analysis}

Optical absorption spectral data of samples synthesized using (9:1, 7:3, 3:2 and 1:1) ratios of leaf extract and $\mathrm{Cu}$ doped $\mathrm{Zn}_{1-\mathrm{x}} \mathrm{O}$ for $\mathrm{x}=0.015$ are listed in Table 4. With the increase in leaf extract ratio, the absorption curve shifted to the longer wavelengths. The red-shift result is associated with the cluster dimensions as it was confirmed on SEM micrographs. 
Table 4: UV-Visible absorption spectra of Zinc oxide nanoparticles synthesized using different ratios of neem leaf aqueous extracts.

\begin{tabular}{lll}
\hline No & Synthesized NPs in different ratio of leave extract & I(nm) \\
\hline 1 & $\mathrm{ZnO}(9: 1)$ & 322 \\
2 & $\mathrm{ZnO}(7: 3)$ & 368 \\
3 & $\mathrm{ZnO}(3: 2)$ & 376 \\
4 & $\mathrm{ZnO}(1: 1)$ & 386 \\
5 & $\left(\mathrm{Zn}_{0.985} \mathrm{Cu}_{0.015} 0\right)(9: 1)$ & 376 \\
\hline
\end{tabular}

Table 5: Zone of inhibition (mm) of ZnO NPs, Cu doped ZnO NPs and composites against gram positive and gram negative bacterial strains.

\begin{tabular}{|c|c|c|c|c|c|}
\hline \multirow[t]{3}{*}{ No } & \multirow[t]{3}{*}{ Bioactive agents } & \multicolumn{4}{|c|}{ Zone of inhibition(mm)(Diameter) } \\
\hline & & \multicolumn{2}{|c|}{ Gram positive bacteria } & \multicolumn{2}{|c|}{ Gram negative bacteria } \\
\hline & & Staphylococcus aureus & Bacillus subtilis & Escherichia coli & Proteus mirabilis \\
\hline 1 & $\mathrm{ZnO}(9: 1)$ & $10 \mathrm{~mm}$ & $6 \mathrm{~mm}$ & $7 \mathrm{~mm}$ & $6 \mathrm{~mm}$ \\
\hline 2 & $\mathrm{ZnO}(7: 3)$ & $12 \mathrm{~mm}$ & $6 \mathrm{~mm}$ & $6 \mathrm{~mm}$ & $6 \mathrm{~mm}$ \\
\hline 3 & $\mathrm{ZnO}(3: 2)$ & $12 \mathrm{~mm}$ & $6 \mathrm{~mm}$ & $6 \mathrm{~mm}$ & $6 \mathrm{~mm}$ \\
\hline 4 & $\mathrm{ZnO}(1: 1)$ & $13 \mathrm{~mm}$ & $6 \mathrm{~mm}$ & $6 \mathrm{~mm}$ & $6 \mathrm{~mm}$ \\
\hline 5 & $\mathrm{Cu}-\mathrm{ZnO}-05$ & $10 \mathrm{~mm}$ & $7 \mathrm{~mm}$ & $6 \mathrm{~mm}$ & $6 \mathrm{~mm}$ \\
\hline 6 & $\mathrm{Cu}-\mathrm{ZnO}-1$ & $8 \mathrm{~mm}$ & $7 \mathrm{~mm}$ & $7 \mathrm{~mm}$ & $6 \mathrm{~mm}$ \\
\hline 7 & Cu-ZnO-15 & $7 \mathrm{~mm}$ & $8 \mathrm{~mm}$ & $8 \mathrm{~mm}$ & $6 \mathrm{~mm}$ \\
\hline 8 & $\star \mathrm{ZnO}(7: 3)$ & $6 \mathrm{~mm}$ & $15 \mathrm{~mm}$ & $6 \mathrm{~mm}$ & $6 \mathrm{~mm}$ \\
\hline 9 & ${ }^{*} \mathrm{Cu}-\mathrm{ZnO} 0-15$ & $6 \mathrm{~mm}$ & $16 \mathrm{~mm}$ & $6 \mathrm{~mm}$ & $6 \mathrm{~mm}$ \\
\hline 10 & Gentamicin & $12 \mathrm{~mm}$ & $14 \mathrm{~mm}$ & $14 \mathrm{~mm}$ & $14 \mathrm{~mm}$ \\
\hline
\end{tabular}

${ }^{\star} \mathrm{ZnO}(7: 3) \&{ }^{*} \mathrm{Cu}-\mathrm{ZnO}-15$ are samples without calcinations

The results in Table 5 showed the microbial activities of $\mathrm{ZnO}$ and copper doped $\mathrm{ZnO}$ NPs synthesized using leaf extract with different ratios. Zone of inhibition for $\mathrm{Cu}$ doped $\mathrm{ZnO}$ NPs increased with the concentration of dopant: $\mathrm{Zn}_{0.995} \mathrm{Cu}_{0.005} \mathrm{O}$ to $\mathrm{Zn}_{0.985} \mathrm{Cu}_{0.015} \mathrm{O}(6 \mathrm{~mm}$ to $8 \mathrm{~mm})$ on Bacillus subtilis and decreased on S.aureus (from $10 \mathrm{~mm}$ to $7 \mathrm{~mm}$ ). Also, inhibitions of 15 and $16 \mathrm{~mm}$ were recorded for ${ }^{*} \mathrm{ZnO}(7: 3)$ and ${ }^{*} \mathrm{Cu}-\mathrm{ZnO}-15$. This might be due to the synergetic effect of leaf extract, $\mathrm{ZnO}$ and $\mathrm{CuO}$ NPs. The influence of the leaf extract ratios and dopant concentration were clearly observed on gram-positive, Staphylococcus aureus bacteria.

\section{Conclusions}

Pure and $\mathrm{Cu}$ doped zinc oxide NPs with wurtzite structures were synthesized using different ratios of neem leaf extract by the co-precipitation method. All the synthesized materials were stable above $400^{\circ} \mathrm{C}$. The microstructure investigation revealed the influence of leaf extract ratios on the morphology of the particles. The antibacterial studies of the synthesized composite materials revealed the synergetic effect of leaf extract, $\mathrm{ZnO}$ and $\mathrm{CuO}$ NPs on the gram-positive Bacillus subtilis.

Conflict of interest: Authors declare no conflict of interest.

\section{References}

[1] Xie Y., He Y., Irwin P. L., Jin T., Shi X., Antibacterial activity and mechanism of action of zinc oxide nanoparticles against Campylobacter jejuni, Appl. Environ. Microbiol., 2011, 77, 232531. http://dx.doi.org/10.1128/AEM.02149-10

[2] Joshi P., Chakraborti S., Chakrabarti P., Singh S.P., Ansari Z.A., Husain M., ZnO Nanoparticles as an Antibacterial Agent Against E. coli, Sci. Adv. Mater., 2012, 4, 173-178, http://dx.doi. org/10.1166/sam.2012.1269 
[3] Jones N., Ray B., K. Ranjit T., Manna A. C., Antibacterial activity of $\mathrm{ZnO}$ nanoparticle suspensions on a broad spectrum of microorganisms, FEMS Microbiol. Lett., 2008, 279, 71-76. http://dx.doi.org/10.1111/j.1574-6968.2007.01012.x

[4] Zhao S.W., Guo C.R., Hu Y.Z., Guo Y.R., Pan Q.J., The preparation and antibacterial activity of cellulose/ZnO composite, Open J. Chem., 2018, 16, 9-20. https://doi.org/10.1515/chem-20180006

[5] Tian Z. R., Voigt J. A., Liu J., Mckenzie B., Mcdermott M. J., Biomimetic arrays of oriented helical $\mathrm{ZnO}$ nanorods and columns, J. Am. Chem. Soc., 2002, 124, 12954-5.https://pubs. acs.org/doi/abs/10.1021/ja0279545

[6] Zhang D., Zhang J., Wu Q., Miu X., Ultraviolet emission of ZnO nano-polycrystalline films by modified successive ionic layer adsorption and reaction technique, J. Sol-Gel Sci. Technol., 2010, 54, 165-173. https://link.springer.com/article/10.1007/ s10971-010-2171-3

[7] Oliveira A.P., Hochepied J.F., Grillon F., Berger M.H., Controlled Precipitation of Zinc Oxide Particles at Room Temperature, Chem. Mater., 2003, 15, 3202-3207. https://pubs.acs.org/ doi/abs/10.1021/cm0213725

[8] Kisailus D., Schwenzer B., Gomm J., Weaver J.C., Morse E., Kinetically controlled catalytic formation of zinc oxide thin films at low temperature, J. Am. Chem. Soc., 2006, 128, 10276-80, https://pubs.acs.org/doi/abs/10.1021/ja062434l

[9] Osmond M.J., McCall M.J, Zinc oxide nanoparticles in modern sunscreens: an analysis of potential exposure and hazard, Nanogk., 2010, 4, 15-41. https://doi. org/10.3109/17435390903502028

[11] Singh A.K., Viswanath V., Janu V.C., Synthesis, the effect of capping agents, structural, optical and photoluminescence properties of ZnO nanoparticles, J. Lumin., 2009, 129, 874-878. https://doi.org/10.1016/j.jlumin.2009.03.027

[12] Shanmugam N., Dhanaraj K., Viruthagiri G., Balamurugan K., Deivam K., Synthesis and characterization of surfactantassisted Mn2+ doped ZnO nanocrystals, Arabian J. Chem., 2016, 9, 758-764. https://doi.org/10.1016/j.arabjc.2011.08.016

[13] Carnes C.L., Klabunde K.J., Synthesis, Isolation, and Chemical Reactivity Studies of Nano-crystalline Zinc Oxide, Langmuir., 2000,16, 3764-3772. https://pubs.acs.org/doi/abs/10.1021/ la991498p

[14] Sharma N., Jandaik S., Kumar S., Synergistic activity of doped zinc oxide nanoparticles with antibiotics: ciprofloxacin, ampicillin, fluconazole and amphotericin $B$ against pathogenic microorganisms, An Acad Bras Cienc., 2016, 88, 1689-1698. http://dx.doi.org/10.1590/0001-3765201620150713.

[15] Khan S.A., Noreen F., Kanwal S., Hussain G., Comparative synthesis, characterization of $\mathrm{Cu}$-doped $\mathrm{ZnO}$ nanoparticles and their antioxidant, antibacterial, antifungal and photocatalytic dye degradation activities, Dig. J. Nanomater. Biostruct., 2017, 12, $877-889$.

[16] Awwad M., Albiss B., Ahmad L., Green synthesis, characterization and optical properties of zinc oxide nanosheets using Olea Europea leaf extract, Adv. Mater. Lett., 2014, 5, 520-524.

[17] Hudlikar M., Joglekar S., Dhaygude M., Kodama K., Latexmediated synthesis of $\mathrm{ZnS}$ nanoparticles: green synthesis approach, J. Nanopart. Res., 2012, 14, 865-70. https://link. springer.com/article/10.1007/s11051-012-0865-x
[18] Singhal G., Bhavesh R., Kasariya K., Sharma A.R, Singh R.P., Biosynthesis of silver nanoparticles using Ocimum sanctum (Tulsi) leaf extract and screening its antimicrobial activity, J. Nanopart. Res., 2011,13, 2981-2988. https://link.springer. com/article/10.1007/s11051-010-0193-y

[19] Yedurkar S., Maurya C., Mahanwar P., Biosynthesis of Zinc Oxide Nanoparticles Using Ixora Coccinea Leaf Extract-A Green Approach, Open J. Synth. Theory Appl., 2016, 5, 1-14. 10.4236/ ojsta.2016.51001

[20] Alagumuthu G., Kirubha R., Green synthesis of silver nanoparticles using Cissusquadrangularis plant extract and their antibacterial activity, Int. J. Nanomater. Biostru., 2012, 2, 30-33.

[21] Mason C., Vivekanandhan S., Misra M., Mohanty A.K., Switchgrass (Panicumvirgatum) extract mediated green synthesis of silver nanoparticles, World J. Nano Sci. Eng., 2012,2, 47-52.

[22] Kundu P., Barik S., Sarkar, K., Bose A., Baral R., Laskar S., Chemical investigation of neem leaf glycoprotein used as immunoprophylactic agent for tumor growth restriction, Int. J. Pharm. Sci., 2015, 7, 195-199.

[23] Soni H., Mishra K., Sharma S., Singhai A. K., Characterization of Azadirachtin from ethanolic extract of leaves of Azadirachtaindica, J. Pharm. Res., 2012, 5, 199-201.

[24] Maurya Y.C., Mahanwar P., Biosynthesis of Zinc Oxide Nanoparticles Using IxoraCoccinea Leaf Extract-A Green Approach, Open J. Synth. Theory Appl., 2016, 5,1-14. 10.4236/ ojsta.2016.51001

[25] Abbasi A., Gharib M., Najafi M., Preparation of ZnO Nanocrystals with Desired Morphology from Coordination Polymers through a Solid-state Decomposition Route, J. Sci., Islamic Repub. Iran., 2016, 27, 217 - 221.

[26] Kulkarni S.S., Mahavidyalaya S., Optical and Structural Properties of Zinc Oxide Nanoparticles, Int. J. Adv. Res. Phys., 2015, 2, 14-18.

[27] Hong R., Li J., Chen L., Liu D., Li H., Zheng Y., Ding J., Synthesis, surface modification and photocatalytic property of ZnO nanoparticles, Powder. Technol, 2009, 189, 426-432. http://dx.doi.org/10.1016/j.powtec.2008.07.004

[28] Thirumavalavan M., Huang K. L., Lee J. F., Preparation and morphology studies of nano zinc oxide obtained using native and modified chitosans, Materials, 2013, 6, 4198-4212. 